\title{
Derrida and Education Today
}

\section{Emile Bojesen $^{1}$ (D)}

Accepted: 10 February 2021 / Published online: 23 February 2021

(c) The Author(s), under exclusive licence to Springer Nature B.V. part of Springer Nature 2021

What can we (still) learn from Jacques Derrida today? Would what we learn be the same lessons as before, over again, perhaps forgotten, misremembered, or in need of refreshing? Can we begin to produce new pedagogical practices influenced by his thought; distilling it, clarifying it? Or else, new modes of educational analysis, allowing us to understand and theorise education more accurately, more 'exactly', more 'truthfully'? What arrives today?

While wary of the 'new', and conscious of the oversimplifications that often accompany distillations, this special issue navigates and negotiates these questions. What is common to all of the four contributions here is a reticence to prescribe, as well as the desire to open up Derrida's thought for events yet to come. These are themselves characteristics of Derrida's thought. Less provisions for practical application than modes of approach to thought, language, and reading; can such approaches nonetheless lead to educational transformation? An argument, no doubt for philosophical education in general, might be that shifts in approach are critical for change. To develop our thinking-conceivably even what might be called our practice of thinking - is both an educational endeavour in itself and an indispensable step in reconfiguring, both in philosophy and pedagogy, how education is investigated, accomplished, and experienced.

But why Derrida? Derrida, again, when there are so many other important philosophers, and already so many advances that have been made in philosophical, social, and educational thought and scholarship since Derrida's death in 2004? Partly, because there are so many avenues left relatively unexplored in his work, not least those to be found in previously unpublished works, or more seemingly peripheral published texts, and also because, as with any scholarship, the questions posed of a particular thinker or topic are themselves tied to the academic and social context within which they arise, at once opening and narrowing points of focus depending on their prescience. This is why we ask, what is it that Derrida offers to us 'today', which will also be tomorrow and the next day, and so on, something different, sometimes, maybe every time. Or, as David Wills puts it, in his translation of Derrida's phrase, 'tout autre est tout autre', 'Every other (one) is every (bit) other.' (2008: 82).

What makes Derrida's thought particularly relevant and responsive to such an approach is that this was itself a key area of focus for him, where time is out of joint. What Michael Naas, in his contribution to this special issue, presents as, 'an argument for the structural revenance that Derrida will have theorized and practiced and undergone and taught from

Emile Bojesen

Emile.bojesen@winchester.ac.uk

1 Department of Education Studies and Liberal Arts, University of Winchester, Winchester, UK 
the very beginning under the name or in the guise - faut le faire - of deconstruction' (Naas 2021). In Naas's reading, there is in both writing and teaching, always necessarily, 'the essential and irreducible non-contemporaneity or non-coincidence of a text or of a seminar, of a pedagogical practice, with itself. The fact that a seminar -may not reach its destination is thus not just the inevitable, and often regrettable, fate of all teaching but also its necessary and irreducible chance.' Concomitantly, Derrida's Theory and Practice seminars (of which, 'faut le faire' [it must be done], is the opening line), not least through Naas's reading of them in his article, are an example of how writing and teaching may reach destinations for which they were not explicitly intended and that could not have been anticipated. In this way, both theory and practice, including theory to be taught through a pedagogical practice, as well as theories of pedagogical practice, can keep arriving, because they are never exhausted in their destination(s).

For philosophy, questions remain equally inexhaustible, their provisional answers ununiform, and reason itself always venturing out from different places, in a great number of trajectories. Deconstruction is no method, Derrida presents no ontology. Instead, he destabilises the very means by which any claims, any promises, any gifts (educational or otherwise), can be made. This destabilisation, though, is not a rendering mute or paralytic but the very invocation of philosophy and its perpetual, albeit always differential and heterogenous, return. This movement is also philosophy's self-deconstruction. It is notable, in Derrida's oeuvre, that he very rarely, almost never, writes without specific reference to texts of other philosophers, writers, and in some instances even invokes multiple of his 'own' voices, seemingly entering into conversation with himself (c.f. Derrida 2007, 2011). These textual conversations are in no way limited to works of classical philosophy, although they also frequently appear. This is one of the reasons why so many have struggled to find his 'magnum opus', or key text, and perhaps why his thought is considered quite difficult to teach. Nevertheless, it also indicates a certain kind of philosophical disposition, directed outward, against its 'own' unification, always (necessarily) responsive to context.

What Derrida shows us, perhaps, is that philosophy can be a conversation, where subjects, meanings, questions, and answers, depend very much on the interlocutors, and where, by having a strong understanding of the conditions in which such conversations take place, deterioration into single or alternating monologue(s) may be avoided. Derrida, as a writer and teacher (c.f. 2002), demonstrates how philosophy may become aware of, and work with rather than against or in ignorance of, its own conditions of inscription (disciplinary, institutional, sociopolitical, economic, broadly 'cultural', and so on), for example within language in general, as well as within and in between seemingly monolithic individual languages. Articles by Emma Williams and Samir Haddad explain how Derrida can be read as being against philosophical, or more general, monolingualism, as well as a 'multilingualism' that perceives supposedly individual languages as internally unified and separate from one another. Instead, he calls for an understanding of languages as at once related to one another as well as 'internally' multiple. This advances an ethical and pedagogical reconfiguration of our relationships to language, where a language is neither our own nor as unified and coherent as we might have been taught to think, while, at the same time, provoking and providing a means to ethical responsiveness.

For Williams (2021), this is closed down by the texts and approaches to texts that are prevalent in language education today. She suggests literature and a less or non-outcomeoriented approach to languages as a more broadly educational and more ethical means of language education. This is not simply a matter of textual or cultural preference but rather attends to how 'reading literature is allowing oneself to be put to work by a text, and where a relation to language is made real and lived through—our structural estrangement and 
unsettlement is vividly present or realised in the experience of language.' To close down these forms of textual engagement has pointed ethical and educational consequences, due to the fact 'that language learning under the global agenda has become less a matter of engagement with literary texts and more a matter of engaging with functional and procedural language for the sake of improving "communication skills" (perhaps themselves most likely to be understood within a business context).' This outcome-oriented approach 'fosters ethical complacency; it also tricks us into a false conception of the nature of 'democratic citizenship' - making the ethical relation to the other appear as a contingent matter that can be opted into, which covers over the ways that our lives are always already lived with others.'

While also drawing on Derrida's critique of monolingualism, Haddad (2021) approaches it in tandem with issues relating specifically to philosophical education. For him, 'it is in the teaching of philosophy, as students are inducted into the discipline, that its languages and modes of expression are imposed'. This is both an opportunity and a risk, as Derrida negotiated extensively in his writings on teaching and educational institutions (c.f. Derrida 2002, 2004). Education, by this measure, 'presents itself as a privileged site to explore the relationship between language and philosophy further' (Haddad 2021). Working through the encroachments, overlaps, and distances between natural languages and their relationships to the language of philosophy, Haddad finds translation itself to be of particular significance, especially within, but also between languages. He shows how translation is crucial for Derrida, in 'disrupting both the desire for a universal language, and the unity drawn between language, State, and philosophy in the traditional reading of Descartes.' Translation is read as a means of resistance to monolingualism 'by promoting complex relations between multiple languages, but also, above all, by challenging the very idea that any one language has a unity, arguing that all languages are multiple within themselves'.

Williams' and Haddad's readings intersect again, when Williams argues that, 'contemporary policies of global education could be seen as effecting in their own way a colonisation of our thinking', and Haddad claims that 'movements of decolonization should not only resist traditional European models of philosophy, but also the European practices of deconstruction that have called these into question.' Thus, while deconstruction can be a means of understanding the colonising practices of global education, it can itself be in danger of succumbing to a form of monolingualism, if it not itself open to multiplication and forms of resistance. In the Theory and Practice seminar that Naas reads, there is a persistent 'questioning [of] the unity of the philosophical tradition itself and, by implication, the unity, self-identity, self-presence, contemporaneity, of the texts and figures considered to be within it.' Derrida himself produced such texts, and is such a figure.

In my own contribution (Bojesen 2021), I explore how Derrida applies this multiplicatory thinking to explicitly educational thought and practice, showing how his work 'pluralizes the ways in which philosophy might be the subject of, or contribute to, education, both within and outside of institutions.' The article shows how Derrida deconstructs the monolanguages of educational philosophy (with particular reference to Rousseau and Hegel), while also mapping the range of possible approaches to the relationship between education and philosophy (notably with implicit reflection on contributions by philosophers, including Jean-François Lyotard and Jacques Rancière, to a conference on 'School and Philosophy' in 1984). Derrida goes to great lengths to illustrate how on every point of definition that can be argued for a philosophical education, other, equally legitimate, albeit seemingly contradictory, theorisations of practices and experiences can exist alongside them. Where Williams and Haddad show, respectively, the dangers of monolinguistic (and superficially multilinguistic) approaches to language education, and the necessity of understanding 
natural and philosophical languages as being subject to the logic of translation, I outline the multiplicity of educational experiences that Derrida suggests fall within the remit of what could be called philosophical education.

Derrida's attentiveness to understanding philosophical education in all its breadth, was, as Naas's contribution helps to show, accompanied by the development of his own everdeveloping pedagogical practices. Furthermore, Derrida's leading contributions to the efforts of Groupe de Recherches sur l'Enseignement Philosophique (GREPH) from 1974 onwards, seeking, among many other objectives, to preserve and extend the teaching of philosophy in French secondary schools, as part of a more general effort to confront rightwing efforts to defund and control education, demonstrates the depth of his commitment to institutionally-oriented philosophical education. These specific examples of his own 'practical' activities, should, as this special issue hopes to show, inform but not limit what the work of Derrida might contribute to educational thought and practice today. Yes, Derrida's thinking can continue to instruct its readers on the ever-present threats of monologic thought in education and beyond, but it can also encourage philosophical and educational dispositions well beyond those he himself practiced. Far from laying down the law on what Derrida has to offer education today, this special issue hopes to provoke his thought's arrival at new destinations, animating new 'translations', showing how it can contribute to contemporary education, as well as the heterogenous invention of forms of education we might not yet have imagined.

Acknowledgements My sincere thanks to: Barbara Thayer-Bacon for her support with this special issue, and her work in tenure as Editor-in Chief of Studies in Philosophy of Education; Emma Williams, Michael Naas, and Samir Haddad for their outstanding contributions; Naomi Waltham-Smith, Thomas Clément Mercier, Eszter Timar, and Jonathan Basile for their extremely generous help with this special issue.

\section{References}

Bojesen, Emile. 2021. Contradictions in Educational Thought and Practice: Derrida, Philosophy, and Education. Studies in Philosophy and Education. https://doi.org/10.1007/s11217-021-09752-1.

Derrida, Jacques. 2008. The Gift of Death. Trans. David Willis. Chicago: The University of Chicago Press.

Derrida, Jacques. 2007. Psyche: Invention of the other in Psyche: Inventions of the Other, Volume I. Eds. Peggy Kamuf and Elizabeth Rottenberg. Stanford, California: Stanford University Press.

Derrida, Jacques. 2011. Pace Not(s) in Parages. Ed. John P. Leavey. Stanford, California: Stanford University Press. pp. 11-102.

Derrida, Jacques. 2002. Who's Afraid of Philosophy?: Right to Philosophy 1. Trans: Plug, J. et al. California: Stanford University Press.

Derrida, Jacques. 2004. Eyes of the University: Right to Philosophy 2. Trans: Plug, J. et al. Stanford: Stanford University Press.

Haddad, Samir. 2021. Derrida on Language and Philosophical Education. Studies in Philosophy and Education. https://doi.org/10.1007/s11217-020-09739-4.

Naas, Michael. 2021. Education in Theory and Practice: Derrida's Enseignement Supérieur. Studies in Philosophy and Education. https://doi.org/10.1007/s11217-020-09723-y.

Williams, Emma. 2021. Language Subjects: Placing Derrida's Monolingualism in Global Education. Studies in Philosophy and Education. https://doi.org/10.1007/s11217-021-09757-w.

Publisher's Note Springer Nature remains neutral with regard to jurisdictional claims in published maps and institutional affiliations. 